\title{
Bacterial wilt disease: host resistance and pathogen virulence mechanisms
}

\author{
Bong-Suk Kim, Elizabeth French, Denise Caldwell, Emily J. Harrington \\ and Anjali S. Iyer-Pascuzzi \\ Department of Botany and Plant Pathology, Purdue University, West Lafayette IN, 47906
}

Email addresses for all authors:

Bong-Suk Kim: kim1@purdue.edu

Elizabeth French: eeckhard@purdue.edu

Denise Caldwell: caldwed@purdue.edu

Emily J. Harrington: ejharrin@purdue.edu

Anjali S. Iyer-Pascuzzi: asi2@purdue.edu

Corresponding author for all stages of publication: Anjali S. Iyer-Pascuzzi, asi2@purdue.edu 


\begin{abstract}
Bacterial wilt (BW), caused by Ralstonia solanacearum, is one of the most destructive bacterial diseases of Solanaceous species worldwide. The species infects plants in more than 200 species and 50 families and was ranked second in a list of the top 10 most scientifically and economically important bacterial plant pathogens(1). The molecular mechanisms underlying resistance and the functions of $\mathrm{R}$. solanacearum effectors are beginning to be uncovered, and much remains to be discovered. In this mini-review, we provide a summary of host resistance and $R$. solanacearum virulence mechanisms, with a focus on tomato.
\end{abstract}

Keywords: Plant disease resistance; tomato; quantitative disease resistance; bacterial pathogen 


\section{Introduction}

$R$. solanacearum infects over 200 plant species throughout the world, but is particularly devastating in the Solanaceae $(2,3)$. The pathogen is soil-borne and thrives in hot, humid environments. In Central America and the Southeastern United States, R. solanacearum is a severe limiting factor to tomato production, where it regularly reduces crop yields. A newly emerged strain, race 3 , biovar 2 is also a severe threat in more temperate regions $(4,5)$.

Bacteria enter the tomato root either in the elongation zone or through wounds created at the site of lateral root emergence (6). Once in the root, bacteria enter the vasculature, which allows them to move from the root to the shoot. $R$. solanacearum produce several pathogenicity factors, including type III effectors, exopolysaccharide (EPS) (7-11)and cell wall degrading enzymes such as cellulase and pectic lyase $(9,12-15)$. As bacteria multiply in the xylem, the amount of EPS increases, ultimately preventing water flow to the shoot, and resulting in shoot wilting and eventual plant death.

Bacterial wilt disease management is difficult, and the best means of control has historically been through resistant cultivars. Resistance in tomato is primarily quantitative, the result of many genes contributing a small amount to resistance(16-23). Although several QTL for resistance to $R$. solanacearum have been coarse-mapped (16-23), none have been fine-mapped or cloned.

R. solanacearumis an extremely diverse species. Older classification schemes divided the pathogen into races and biovars (2). The race designation was based on the host range of the pathogen. Within races, $R$. solanacearum was divided into biovars, based in part on the ability of the pathogen to degrade specific carbohydrates(24). However, as the diversity of the species became clear through phylogenetic analyses, the race-biovar designations were changed $(25,26)$. Currently, $R$. solanacearum is classified according to phylotype and sequevar and is known as the Ralstonia solanacearum species complex (RSSC) (25). The RSSC is divided into four phylotypes, which each correspond (approximately) to a different geographic region. Phylotype I is found in Asia, Phylotype II (A and B) in the Americas, Phylotype III in Africa, and Phylotype IV in the Australia-Indonesia region. Phylotypes subsequently are divided into sequevars. Strains in phylotype IIA are found in the southeastern United States and the Caribbean, and typically infect plants in the Solanaceae. Strains in Phylotype IIB include the select agent strain of $R$. solanacearum (old designation race 3 biovar 2) that can infect plants at lower temperatures than other strains $(4,5)$. Phylogenetic analyses have shown little correlation between host range and phylotypes $(10,26)$.

The genomes of at least 14 different RSSC strains have been completely sequenced (27). These 14 include representatives from all four RSSC phylotypes, including the phylotype II type strain K60 (28), and the phylotype I strain GMI1000 frequently used in laboratory studies (29). Sequencing has been instrumental not only in classification but also in the identification of virulence determinants.

In this mini-review, we provide an overview of host genetic resistance and bacterial virulence mechanisms. For more detailed reviews see $(10,26,30,31)$.

\section{Host resistance mechanisms}

Genetic Mechanisms of Resistance

BW resistance in tomato is largely quantitative (polygenic). Although in Arabidopsis, resistance to $R$. solanacearum is governed by at least one major gene, $R R S 1-R(32)$, no major genes for BW resistance have been identified in tomato. Several QTL for BW resistance have 
been mapped to regions of the tomato genome (16-23). These are both strain-specific and broadspectrum QTL and include a large QTL on chromosome 12 to a Taiwanese phylotype I strain $(21,23)$, weaker QTL on chromosome 6 to both phylotype I and II strains(17-23), and additional small possibly strain-specific QTLs on chromosomes 3, 4 and 8 (22). Most of these QTL were identified using the same recombinant inbred line (RIL) population, Hawaii7996 (HA) $\mathrm{x}$ WestVirginia700 (WVa700). HA is unusual in that it has strong resistance in a wide variety of geographic locations throughout the world (3). The published QTL data suggest that HA contains multiple loci contributing to resistance to several $R$. solanacearum strains.

Thus far, the strongest QTL for BW resistance to any $R$. solanacearum strain maps to a $2.8 \mathrm{cM}$ region on chromosome 12 . Bwr-12 is effective against phylotype I (Asian) strains, accounting for approximately $18-56 \%$ of the resistance $(21,23)$. This QTL does not appear to be active against phylotype II strains (22).

The other major QTL for BW resistance, Bwr-6, localizes to a $15.5 \mathrm{cM}$ region on the short arm of tomato chromosome 6 and is effective against both phylotype I and II strains (1723). QTL in this region have mapped to slightly different areas of this region in four separate experiments (all in the HA x Wva700 RILs). It is unclear exactly how many QTL are in this region.Bwr-6 explains approximately $11.5-22 \%$ of the variation in resistance to $R$. solanacearum (23). This region appears to be a 'hot-spot' for both qualitative and quantitative disease resistance genes. Resistance genes that map to this region include $M i$ for resistance to root-knot nematodes and potato aphids (33-35), Cf2 and Cf5 for resistance to Cladosporium fulvum(36), and the QTL Ol-1 for resistance to Oidium lycopersicon(37), Ty-1 for resistance to Tomato yellow leaf curlvirus(38), and Am, for resistance to Alfalfa mosaic virus(39).

In Arabidopsis, resistance to $R$. solanacearum is conferred by the combined action of two NB-LRR genes, RRS1-R (resistance to Ralstonia solanacearum 1) and RPS4 (resistance to Pseudomonas syringae 4)(40-46). Together these act to confer recognition of the type III effectors (T3Es) PopP2 from R. solanacearum and AvrRps4 from Pseudomonas syringae. RRS1$R$ is unusual in that it not only encodes the only known recessive NB-LRR $R$ gene but the protein also contains a WRKY DNA binding domain(32). The T3E PopP2, an acetyltransferase, directly acetylates a specific lysine within the C-terminal WRKY transcription factor domain of RRS1$\mathrm{R}(47)$. This disrupts the connection between RRS1-R and DNA, leading to the activation of RPS4-induced defenses $(45,46)$. Thus, $R R S 1-R$ acts as an 'integrated decoy': it uses the WRKY domain as an effector target but can activate defense signaling through a different NBS-LRR protein. Thus, it is able to preventeffector virulence and activate defense genes $(45,46,48)$.

\section{Host whole genome transcription profiling}

Given the importance of $R$. solanacearum, surprisingly little information is known regarding the transcriptional responses of plants to $R$. solanacearum infection. A time-course of transcriptional changes viewed by microarray analysis of $R$. solanacearum infection in Arabidopsis found that many hormone-related genes were affected (49). At early wilting stages (5 days after inoculation), 471 genes were differentially expressed in the compatible interaction compared to the incompatible. Most (353) were upregulated, and 40\% of these genes were involved in the biosynthesis or signaling of the plant hormone abscisic acid (ABA). This is consistent with the idea that during early wilting stages bacteria-produced EPS restricts water flow throughout the plant, and ABA plays a major role in water stress. Many down-regulated genes at the early wilting stage were related to auxin and cytokinin signaling (49). 
Because tomato has a different type of resistance to $R$. solanacearum compared to Arabidopsis (poly- vs. monogenic) and pathogenesis of the bacteria within each host appears to be different (49), work directly in tomato is crucial for understanding resistance and disease mechanisms. Examination of tomato transcriptional responses in a resistant and susceptible line with microarrays 24 hours after inoculation showed no change in gene expression in the inoculated susceptible plant relative to the mock-inoculated susceptible plant, but identified 146 up-regulated and 10 down-regulated genes in the resistant plant (50). Many different hormonerelated genes were differentially expressed in the resistant cultivar, including those with roles in the jasmonic acid, auxin, and ethylene signaling pathways. PR (pathogenesis-related) genes as well as lignin and hydroxyl cinnamic acid biosynthesis genes were also upregulated, suggesting that gene expression changes leading to alterations in cell wall structure within xylem vessels may be important for resistance (50).In both the transcriptional profiling reports, shoots were sampled for gene expression, but since roots are part of the natural infection process, and are an important part of resistance $(51,52)$, it is likely that knowledge of root transcriptional reprogramming will provide important information for deciphering resistance mechanisms.

\section{Roots are an important part of resistance}

Studies with grafting have demonstrated that roots are key to resistance. Grafting resistant rootstocks to susceptible scions is an effective means of disease control in the Southern United States as well as South Korea and Japan $(51,52)$. Scions of the susceptible BHN 602 tomato line were grafted onto rootstocks of various tomato lines with resistance to bacterial wilt (51). When disease pressure was low, BW incidence of both grafted and non- or self-grafted was low. When BW disease pressure was high, both fruit yield and BW incidence from grafted hybrids performed much better than non-grafted and self-grafted hybrids (51). Grafting resistant rootstocks had similar effects on resistance in susceptible scions in a field study in North

Carolina (52). These studies demonstrate the importance of roots for resistance and tomato yield in the field.

\section{Insights to resistance from histological studies}

Several groups have used histological studies to provide insight into how plants are affected by $R$. solanacearum.R. solanacearum is thought to enter the root system through secondary roots, root cap or through wounds acquired in the soil(2). In susceptible tomatoes, $R$. solanacearum entry into roots occurs in four stages (6): Bacteria first colonize the root surface either in the elongation zone or at the point of emerging lateral roots. During the second stage of colonization, 2 - 3 days after inoculation, significant numbers of bacteria infect the cortex, an inner layer of the root, with smaller numbers found in the epidermis, an outer root layer. Bacteria enter the vasculature, including the xylem, and begin to degrade cell walls during the third stage of infection, about 3 days after inoculation. In the fourth stage, bacteria multiply and begin to move into the shoot. The increase in EPS in the root and shoot plugs the xylem, preventing water movement, and leading to wilt, the most recognizable disease symptom.

The infection process is less well understood in resistant plants. Multiple reports have shown that resistant cultivars have significant numbers of bacteria within both roots and shoots, although the multiplication of bacteria in resistant plants may be slower (9), and in general, susceptible plants have higher levels of bacteria in the stem. Several reports suggest that bacteria in resistant plants are distributed differently than in susceptible plants, and are limited in their ability to broadly colonize tissues $(53)$. Grimault et al. $(53,54)$ showed that resistance was 
significantly correlated with bacterial colonization in the mid-stem. Consistent with this, QTL controlling $R$. solanacearum race 3 colonization in tomato stems were recently identified (22). There appear to be two types of resistance mechanisms in the stem that both block bacterial movement, but in different ways. Examination of bacteria distribution in stems of resistant and susceptible lines found that resistant lines confined bacteria to the primary xylem, possibly through thickenings of pit membranes in stem xylem tissue (55). In the susceptible line bacteria were found in secondary xylem tissues of the stem or had moved into the pith (55). A second means of preventing bacterial movement may be through the accumulation of tyloses in stem xylem vessels (53). Tyloses are outgrowths of xylem parenchyma cells that balloon into the lumen of adjacent xylem vessels, creating a physical barrier that may prevent bacterial movement.

Experiments inMedicago truncatulashowed that as in tomato, $R$. solanacearumenters the intercellular spaces of the root cortex and proceeds to the vascular cylinder to allow colonization of the vascular system(56). Bacteria were identified in both resistant and susceptible cultivars but with higher numbers in susceptible plants. As in tomato, once bacteria accessed the central vascular system they were able to rapidly reproduce within the xylem vessel.

The infection process appears to be somewhat similar inArabidopsis thalianaroots grown on agar media. Digonnet et al.(57) found that six days post inoculationbacteria are found within intercellular spaces of the root cortex.Cell wall degradation allowed the bacteria to enter into the vascular system and multiply, and bacterial pockets to form within xylem vessels (57) of susceptible plants.

\section{Environmental Mechanisms of Resistance}

Biocontrol

In recent years, many studies have investigated the use of beneficial microorganisms as biocontrol agents (BCAs) for plant diseases. The most commonly studied microorganisms for the purpose of controlling BWare bacteria (58). Most researchers have focused on avirulent strains of R. solanacearum, Pseudomonas spp, and Bacillus spp., although other species have been used as well. BCAscan suppress disease through multiple mechanisms including competition, production of cell-wall degrading enzymes, antibiotics, or siderophores, and induction of systemic resistance (58). A common strategy for identifying potential BCAs is to isolate them from the rhizospheres of healthy plants (59). However, isolating microorganisms from the rhizospheres of $R$. solanacearum-infected plants to enrich for bacteria with biocontrol capabilities against BW may be a more effective strategy (60).

Hyakumachi et al. (61)showed that soil pretreatment with either a cell culture or cell-free filtrate of Bacillus thuringiensis suppresses tomato bacterial wilt and induces expression of defense-related genes. In a follow-up study, they examined transcription patterns in tomato roots pretreated with $B$. thuringiensis cell-free filtrate and subsequently challenged with $R$. solanacearum(62). Salicylic acid (SA)-related defense genes were induced only in main roots, but not in lateral roots, while jasmonic acid (JA)-dependent defense genes were either suppressed or not induced. Ethylene (ET)-responsive genes were induced in both main and lateral roots. Taken together, these results suggest that $B$. thuringiensis mediated disease suppression involves co-activation of SA and ET defense hormone signaling pathways and simultaneous suppression of the JA pathway, which is different than the classic model of induced systemic resistance mediated by activation of JA and ET (63). In an early study on biocontrol of BW, pretreatment 
with the oomycete Pythium oligandrum transiently induced ET production and expression of ETrelated genes and subsequently reduced wilt symptoms (64).

Various rhizosphere-inhabiting fungi have also been found to induce resistance against tomato bacterial wilt. Many studies have focused on mycorrhizal fungi, which develop a symbiotic relationship with plant roots and have also been shown in some cases to induce systemic resistance against plant disease. An early study found that colonization by Glomus versiformae induced phenol production in tomato roots and protected them against $R$. solanacearum infection (65). A more recent investigation characterized three different endomycorrhizal fungi for their biocontrol capabilities and found that bacterial wilt disease suppression varied between fungal species (66).

\section{Soil amendments}

Several different types of soil amendments have also been shown to provide efficient control for tomato bacterial wilt. Tomatoes grown in soil amended with $20 \%$ (v/v) municipal waste biochar, a charcoal-like substance for soil application in agriculture, had a reduced disease incidence compared to tomatoes grown in un-amended soil or soil amended with a wood biochar(67). Addition of bioorganic fertilizer decreased soil $R$. solanacearum populations and reduced disease incidence in tomato field plots compared to plots treated with either an inorganic or organic NPK fertilizer (68). The bioorganic fertilizer, which contains its own populations of bacteria, increased the diversity and richness of the bacterial populations in the amended soil, which was correlated with increased disease resistance. Soil application of systemic resistance elicitors - silicon and chitosan - also reduced bacterial wilt disease incidence and severity and increased expression of defense-related genes, such as chitinases and peroxidases (69). Another study examining silicon-induced resistance to tomato bacterial wilt showed that silicon amendment primed tomato plants for JA-/ET- and reactive oxygen species- dependent defense gene expression, increasing their resistance to disease (70). For a more comprehensive review of biocontrol and soil amendment disease control for bacterial wilt, see Yuliar, et al., (58).

\section{Pathogen Effectors and other Virulence Factors}

Non-type III effector Virulence factors

$R$. solanacearum uses numerous virulence factors during the disease process. The pathogen secretes exopolysaccharide (EPS1), a polymer of N-acetylated sugars and a major virulence factor for infection in tomato (10). EPS1 deficient strains cause significantly less disease in tomato regardless of whether they are inoculated onto unwounded root systems or directly into the xylem $(9,11)$. In resistant tomato plants, wild type $R$. solanacearum induced greater defense responses than the eps ${ }^{-}$mutant, suggesting that resistant plants can recognize this pathogen trait (11). Coincident with this, $R$. solanacearum growing in roots of infected resistant tomato plants produce less EPS per gram of tissue than those found in susceptible plants(8). The production of EPS1 is regulated by cell density, and is higher when pathogen density is greater than $10^{7}$ cells $/ \mathrm{ml}$ (71).In addition to high cell density, EPS1 production requires nitrogen in the form of nitrate. Mutants defective in nasA, which encodes a nitrate reductase, do not produce normal amounts of EPS1 (72).

Other virulence factors in both tomato and Arabidopsis include cell wall degrading enzymes $(13,73-75)$, which are secreted through $R$. solanacearum's type II protein secretion system (T2SS)(26). Both pectolyctic and cellulolytic wall degrading enzymes in $R$. solanacearum have been described. A $R$. solanacearum mutant defective in the T2SS has only weak 
virulence(76), and isless virulent than mutants defective only in CWDE, suggesting that in addition to CWDE, other proteins secreted through the T2SS are important for virulence (14). Surprisingly, a triple mutant defective in three pectolytic enzymes was more virulent than either a mutant defective in six CWDE (both pectolytic and cellulolytic)(75)or two cellulolytic enzymes. The authors attribute this to a lack of plant defense stimulation in the triple mutant (75). Similar to infection in tomato, CWDE are important for $R$. solanacearum infection in Arabidopsis. Inoculation with $R$. solanacearum GMI1000 resulted in pectin degradation in the root of wild-type Col-0 Arabidopsis (57).

Another significant aspect of $R$. solanacearum virulence is motility. Nonmotile mutants that either lacked flagella or had defective flagella had reduced virulence when soil-soak inoculated on tomato(77). However, when the nonmotile fliC mutant was inoculated directly into the xylem via petiole inoculation, it was able to cause disease (77). These data suggest that flagella are important for locating roots but are dispensable once bacteria have reached the xylem. Twitching motility, which provides a flagella-independent form of surface movement for $R$. solancearum, also plays a role in virulence (78), as mutants defective in this ability show reduced virulence in tomato (78).

How $R$. solanacearum thrives in the oxygen- and nutrient-limited environment of the xylem has been puzzling. However, recent work has demonstrated that the ability to use nitrate is an important part of $R$. solanacearum virulence in tomato $(72,79,80) . R$. solanacearum infection reduces already low levels of oxygen in the xylem(80). Tomato xylem sap contains significantly high levels of nitrate. Work by Dalsing et al. 2015 (80)showed that during infection, $R$. solanacearum consumed the available oxygen, and was able to use inorganic $\mathrm{N}$ as an energy source with nitrate as a terminal electron acceptor. Consistent with this, the genome of GMI1000, a phylotype I strain of $R$. solanacearum, contains a set of nitrate respiration and denitrification genes (narG, aniA, norB, nosZ and $h m p X)(29,80)$. Further, transcriptomic analysis of bacteria growingin planta showed that all of these genes were significantly expressed during $R$. solanacearum pathogenesis in tomato (79). Single mutant analysis showed that two mutants with defects in the nitrate detoxification pathway, aniA and $h m p X$, caused less wilt disease than wild type $R$. solanacearum(80). Thus, the ability to use inorganic $\mathrm{N}$ is an important part of the pathogen's ability to colonize the tomato host and cause disease.

\section{Pathogen Effectors and the T3SS}

Like most plant pathogens, $R$. solanacearumuses the type III secretion system (T3SS) to inject type III effectors (T3Es) into the host cell, causing disease in susceptible plants and defense responses in resistant plants (30). hrp genes are induced in planta, and $R$. solanacearum is thus far the only species in which induction of hrp genes has been shown to require physical contact between the bacterium and the plant host cell wall (81-84). InR. solanacearum, an outer membrane receptor known as PrhA recognizes a non-diffusible plant cell wall molecule and initiates a transcriptional cascade that results in the activation of the master regulatorhrpG, followed by $h r p B$. HrpB then directly controls the expression of the T3SS machinery and T3E expression(26).In addition to its role in activating the T3SS through $h r p B$, HrpG also directs the expression of hundreds of $h r p B$-independent genes that are important for pathogen virulence (15, $85)$. The $h r p B$ regulon is expressed in planta both at early stages of plant infection and during later wilting stages $(79,86)$. Both $h r p B$ and $h r p G$ genes are necessary for tomato root infection, although at different stages of the process (87). 
Genomic sequencing has revealed that $R$. solanacearum strains have, on average, between 60 - 75 different T3Es $(27,31)$, several of which are part of multigene families. About $50 \%$ of the predicted T3Es in the RSSC are thought to be specific to this species complex (26), and many are highly conserved within phylotypes. For example, within phylotype II, 54 effectors are conserved among four sequenced strains (26). Thirty-two effectors are conserved across at least 10 of the fully sequenced RSSC genomes (31), although a minimal set of "core" effectors has not yet been identified. Despite the effector conservation within phylotype, there appears to be little correlation between host range and phylotype (26).

Of the predicted 110 T3E gene families in the RSSC (26), only about two dozen have a known function (30). Genetic analyses have demonstrated that several T3Es have roles in $R$. solanacearum virulence. For example, PopS and GALA4 suppress plant defenses in tomato (79, 88), while GALA7 is required for virulence in Medicago truncatula(56). In tobacco cells, PopA localizes to the membrane and forms an ion-conducting pore, which may promote translocation of bacterial proteins from the apoplast into the host cell cytoplasm (89). Effectors in the RSSC also have roles in avirulence. AvrA is a major avirulence factor in tobacco(90, 91), while PopP2 interacts with the Arabidopsis resistance protein RRS1-R (32). However, effector function is dependent on host species, as both AvrA and PopP2 contribute to pathogen growth in tomato (AvrA and PopP2) (92) or Medicago truncatula (AvrA) (56). Depending on the strain, the $R$. solanacearumgenome also contains effectors that are homologs of Xanthomonas TAL effectors, known as RipTALs in $R$. solanacearum(27, 93, 94).

In part due to the prevalence of gene families among RSSC effectors, multiple mutations are often necessary to see a reduction in virulence. For example, knocking out all five members of the AWR gene family causes reduced virulence in tomato (95). A triple mutant in members of the HLK family also shows a reduction in virulence (96). The GALA T3E family contains eight genes that encode proteins with F-box motifs (97). Four members of this family interact with Arabidopsis Skp-1 like proteins, suggesting they may be involved in proteasome-mediated degradation of plant host targets (97). Mutants lacking all sevenGALA genes in GMI1000 have reduced virulence in Arabidopsis, tomato, and eggplant(88). For a more detailed description of T3Es in $R$. solanacearum, the reader is referred to $(10,26,30,31)$.

Understanding the $R$. solanacearum genes used during pathogenesis is helping to shed light on virulence mechanisms in planta. For example, using a strain of $R$. solanacearum expressing a luminescent reporter Montiero et al. (86)showed that the gene controlling EPS biosynthesis is activated in bacteria that colonize the xylem. In a different study, examination of gene expression from two strains of $R$. solanacearumin planta identified genes that were differentially expressed in tomatoduring early bacterial wilt disease (79). Surprisingly, $45 \%$ of HrpB- regulated genes were upregulated in planta, suggesting that T3SS has an important role throughout the disease cycle. Virulence factors such as EPS1 biosynthesis genes and mobility genes ( $p i l A$ and $f l i C$ ) were expressed highly during pathogenesis, as were pathways for sucrose uptake and metabolism. Sucrose regulon genes were upregulated significantly in planta. A mutant defective in the scrAgene was less virulent than the wild type pathogen when inoculated to unwounded tomato roots, but not when introduced to the xylem through cut petioles. However, calculation of the population size of the wild type and scrA mutant in the xylem during wilting showed a reduction in scrA growth, suggesting that the scrA mutant had a reduction in fitness during pathogenesis(79). Knowledge of the $R$. solanacearum genes active during infection will lead to greater understanding of host resistance and susceptibility. 


\section{Conclusions}

In conclusion, $R$. solanacearum is a diverse pathogen that uses a battery of virulence mechanisms to cause disease. While there is still much to be learned about host plant resistance, mechanisms of pathogen virulence are becoming clearer. Future studies will continue to investigate pathogen virulence mechanisms and will generate insight into host plant resistance through QTL cloning, examination of the molecular mechanisms of resistance in roots, and through the identification of additional plant proteins targeted by $R$. solanacearum effectors.

\section{Acknowledgements}

We thank members of the Iyer-Pascuzzi lab for comments and Purdue University for funding. EF is supported by a NSF graduate research fellowship.

\section{References}

1. Mansfield J, Genin S, Magori S, Citovsky V, Sriariyanum M, Ronald P, Dow M, Verdier V, Beer SV, Machado MA, Toth I, Salmond G, Foster GD. Top 10 plant pathogenic bacteria in molecular plant pathology. Mol Plant Pathol 2012; 13(6): 614-629.

2. Hayward AC. Biology and Epidemiology of Bacterial Wilt Caused by PseudomonasSolanacearum. Annual Review of Phytopathology 1991; 29: 65-87.

3. Scott JW, Wang JF, Hanson PM. Breeding tomatoes for resistance to bacterial wilt, a global view. Proceedings of the 1st International Symposium on Tomato Diseases 2005; (695): 161-172.

4. Norman DJ, Zapata M, Gabriel DW, Duan YP, Yuen JM, Mangravita-Novo A, Donahoo RS. Genetic diversity and host range variation of Ralstonia solanacearum strains entering North America. Phytopathology 2009; 99(9): 1070-1077.

5. Clarke CR, Studholme DJ, Hayes B, Runde B, Weisberg A, Cai R, Wroblewski T, Daunay MC, Wicker E, Castillo JA, Vinatzer BA. Genome-Enabled Phylogeographic Investigation of the Quarantine Pathogen Ralstonia solanacearum Race 3 Biovar 2 and Screening for Sources of Resistance Against Its Core Effectors. Phytopathology 2015; 105(5): 597-607.

6. Vasse J, Frey P, Trigalet A. Microscopic Studies of Intercellular Infection and Protoxylem Invasion of Tomato Roots by Pseudomonas-Solanacearum. Molecular PlantMicrobe Interactions 1995; 8(2): 241-251.

7. Denny T, Baek S. Genetic evidence that extracellular polysaccharide is a viurlence factor of Pseudomonas solanacearum. Mol Plant Microbe Interactions 1991; 4: 198-206.

8. McGarvey JA, Denny TP, Schell MA. Spatial-temporal and quantitative analysis of growth and EPSI production by Ralstonia solanacearum in resistant and susceptible tomato cultivars. Phytopathology 1999; 89(12): 1233-1239. 
9. Saile E, McGarvey JA, Schell MA, Denny TP. Role of Extracellular Polysaccharide and Endoglucanase in Root Invasion and Colonization of Tomato Plants by Ralstonia solanacearum. Phytopathology 1997; 87(12): 1264-1271.

10. Genin S. Molecular traits controlling host range and adaptation to plants in Ralstonia solanacearum. New Phytol 2010; 187(4): 920-928.

11. Milling A, Babujee L, Allen C. Ralstonia solanacearum extracellular polysaccharide is a specific elicitor of defense responses in wilt-resistant tomato plants. PLoS One 2011; 6(1): e15853.

12. Allen C, Gay J, Simon-Buela L. A regulatory locus, pehSR, controls polygalacturonase production and other virulence functions in Ralstonia solanacearum. Mol Plant Microbe Interact 1997; 10(9): 1054-1064.

13. Huang Q, Allen C. An exo-poly-alpha-D-galacturonosidase, PehB, is required for wildtype virulence of Ralstonia solanacearum. J Bacteriol 1997; 179(23): 7369-7378.

14. Liu H, Zhang S, Schell MA, Denny TP. Pyramiding unmarked deletions in Ralstonia solanacearum shows that secreted proteins in addition to plant cell-wall-degrading enzymes contribute to virulence. Mol Plant Microbe Interact 2005; 18(12): 1296-1305.

15. Valls M, Genin S, Boucher C. Integrated regulation of the type III secretion system and other virulence determinants in Ralstonia solanacearum. PLoS Pathog 2006; 2(8): e82.

16. Young ND, Danesh D. Understanding Bacterial Wilt Resistance in Tomato through the Use of DNA Genetic-Markers. Bacterial Wilt 1994: 145-155.

17. Danesh D, Aarons S, McGill GE, Young ND. Genetic Dissection of Oligogenic Resistance to Bacterial Wilt in Tomato. Mol Plant Microbe Interact 1994; 7(4): 464-471.

18. Thoquet P, Olivier J, Sperisen C, Rogowsky P, Laterrot H, Grimsley N. Quantitative trait loci determining resistance to bacterial wilt in tomato cultivar Hawaii7996. Molecular Plant-Microbe Interactions 1996; 9(9): 826-836.

19. Thoquet P, Olivier J, Sperisen C, Rogowsky P, Prior P, Anais G, Mangin B, Bazin B, Nazer R, Grimsley N. Polygenic resistance of tomato plants to bacterial wilt in the French West Indies. Molecular Plant-Microbe Interactions 1996; 9(9): 837-842.

20. Mangin B, Thoquet P, Olivier J, Grimsley NH. Temporal and multiple quantitative trait loci analyses of resistance to bacterial wilt in tomato permit the resolution of linked loci. Genetics 1999; 151(3): 1165-1172.

21. Wang JF, Olivier J, Thoquet P, Mangin B, Sauviac L, Grimsley NH. Resistance of tomato line Hawaii7996 to Ralstonia solanacearum Pss4 in Taiwan is controlled mainly 
by a major strain-specific locus. Molecular Plant-Microbe Interactions 2000; 13(1): 613.

22. Carmeille A, Caranta C, Dintinger J, Prior P, Luisetti J, Besse P. Identification of QTLs for Ralstonia solanacearum race 3-phylotype II resistance in tomato. Theor Appl Genet 2006; 113(1): 110-121.

23. Wang J-F, Ho F-I, Truong HTH, Hugan S-M, Balatero CH, Dittapongpitch V, Hidayati N. Identification of major QTLs associated with stable resitance of tomato cultivar 'Hawaii 7996' to Ralstonia solanacearum. Euphytica 2013; 190: 241-252.

24. Denny TP, Hayward AC. Ralstonia, 3rd edn. APS Press, 2001.

25. Fegan M, Prior P. How complex is the Ralstonia solanacearum species complex? In: C. Allen PP, and A.C. Hayward (ed). Bacterial Wilt: The Disease and the Ralstonia solanacearum Species Complex. American Phytopathological Society Press: St. Paul, MN, USA, 2005, pp 449-461.

26. Genin S, Denny TP. Pathogenomics of the Ralstonia solanacearum species complex. Annu Rev Phytopathol 2012; 50: 67-89.

27. Peeters N, Carrere S, Anisimova M, Plener L, Cazale AC, Genin S. Repertoire, unified nomenclature and evolution of the Type III effector gene set in the Ralstonia solanacearum species complex. BMC genomics 2013; 14: 859.

28. Remenant B, Babujee L, Lajus A, Medigue C, Prior P, Allen C. Sequencing of K60, type strain of the major plant pathogen Ralstonia solanacearum. J Bacteriol 2012; 194(10): 2742-2743.

29. Salanoubat M, Genin S, Artiguenave F, Gouzy J, Mangenot S, Arlat M, Billault A, Brottier P, Camus JC, Cattolico L, Chandler M, Choisne N, Claudel-Renard C, Cunnac S, Demange N, Gaspin C, Lavie M, Moisan A, Robert C, Saurin W, Schiex T, Siguier P, Thebault P, Whalen M, Wincker P, Levy M, Weissenbach J, Boucher CA. Genome sequence of the plant pathogen Ralstonia solanacearum. Nature 2002; 415(6871): 497502.

30. Coll NS, Valls M. Current knowledge on the Ralstonia solanacearum type III secretion system. Microbial biotechnology 2013; 6(6): 614-620.

31. Deslandes L, Genin S. Opening the Ralstonia solanacearum type III effector tool box: insights into host cell subversion mechanisms. Current opinion in plant biology 2014; 20: 110-117.

32. Deslandes L, Olivier J, Peeters N, Feng DX, Khounlotham M, Boucher C, Somssich I, Genin S, Marco Y. Physical interaction between RRS1-R, a protein conferring resistance 
to bacterial wilt, and PopP2, a type III effector targeted to the plant nucleus. Proc Natl Acad Sci U S A 2003; 100(13): 8024-8029.

33. Rossi M, Goggin FL, Milligan SB, Kaloshian I, Ullman DE, Williamson VM. The nematode resistance gene $\mathrm{Mi}$ of tomato confers resistance against the potato aphid. Proc Natl Acad Sci U S A 1998; 95(17): 9750-9754.

34. Milligan SB, Bodeau J, Yaghoobi J, Kaloshian I, Zabel P, Williamson VM. The root knot nematode resistance gene Mi from tomato is a member of the leucine zipper, nucleotide binding, leucine-rich repeat family of plant genes. The Plant cell 1998; 10(8): 1307-1319.

35. Vos P, Simons G, Jesse T, Wijbrandi J, Heinen L, Hogers R, Frijters A, Groenendijk J, Diergaarde P, Reijans M, Fierens-Onstenk J, de Both M, Peleman J, Liharska T, Hontelez $\mathrm{J}$, Zabeau M. The tomato Mi-1 gene confers resistance to both root-knot nematodes and potato aphids. Nature biotechnology 1998; 16(13): 1365-1369.

36. Dickinson MJ, Jones DA, Jones JD. Close linkage between the $\mathrm{Cf}-2 / \mathrm{Cf}-5$ and $\mathrm{Mi}$ resistance loci in tomato. Mol Plant Microbe Interact 1993; 6(3): 341-347.

37. van der Beek JG, Pet G, Lindhout P. Resistance to powdery mildew (Oidium lycopersicum) in Lycopersicon hirsutum is controlled by an incompletely-dominant gene Ol-1 on chromosome 6. Theor Appl Genet 1994; 89(4): 467-473.

38. Zamir D, Ekstein-Michelson I, Zakay Y, Navot N, Zeidan M, Sarfatti M, Eshed Y, Harel E, Pleban T, van-Oss H, Kedar N, Rabinowitch HD, Czosnek H. Mapping and introgression of a tomato yellow leaf curl virus tolerance gene, TY-1. Theor Appl Genet 1994; 88(2): 141-146.

39. Parrella G, Moretti A, Gognalons P, Lesage ML, Marchoux G, Gebre-Selassie K, Caranta C. The Am Gene Controlling Resistance to Alfalfa mosaic virus in Tomato Is Located in the Cluster of Dominant Resistance Genes on Chromosome 6. Phytopathology 2004; 94(4): 345-350.

40. Narusaka M, Shirasu K, Noutoshi Y, Kubo Y, Shiraishi T, Iwabuchi M, Narusaka Y. RRS1 and RPS4 provide a dual Resistance-gene system against fungal and bacterial pathogens. The Plant journal : for cell and molecular biology 2009; 60(2): 218-226.

41. Narusaka M, Kubo Y, Shiraishi T, Iwabuchi M, Narusaka Y. A dual resistance gene system prevents infection by three distinct pathogens. Plant signaling \& behavior 2009; 4(10): 954-955.

42. Narusaka M, Kubo Y, Hatakeyama K, Imamura J, Ezura H, Nanasato Y, Tabei Y, Takano Y, Shirasu K, Narusaka Y. Breaking restricted taxonomic functionality by dual resistance genes. Plant signaling \& behavior 2013; 8(6): e24244. 
43. Narusaka M, Hatakeyama K, Shirasu K, Narusaka Y. Arabidopsis dual resistance proteins, both RPS4 and RRS1, are required for resistance to bacterial wilt in transgenic Brassica crops. Plant signaling \& behavior 2014; 9(7): e29130.

44. Sohn KH, Segonzac C, Rallapalli G, Sarris PF, Woo JY, Williams SJ, Newman TE, Paek $\mathrm{KH}$, Kobe B, Jones JD. The nuclear immune receptor RPS4 is required for RRS1SLH1dependent constitutive defense activation in Arabidopsis thaliana. PLoS genetics 2014; 10(10): e1004655.

45. Le Roux C, Huet G, Jauneau A, Camborde L, Tremousaygue D, Kraut A, Zhou B, Levaillant M, Adachi H, Yoshioka H, Raffaele S, Berthome R, Coute Y, Parker JE, Deslandes L. A receptor pair with an integrated decoy converts pathogen disabling of transcription factors to immunity. Cell 2015; 161(5): 1074-1088.

46. Sarris PF, Duxbury Z, Huh SU, Ma Y, Segonzac C, Sklenar J, Derbyshire P, Cevik V, Rallapalli G, Saucet SB, Wirthmueller L, Menke FL, Sohn KH, Jones JD. A Plant Immune Receptor Detects Pathogen Effectors that Target WRKY Transcription Factors. Cell 2015; 161(5): 1089-1100.

47. Tasset C, Bernoux M, Jauneau A, Pouzet C, Briere C, Kieffer-Jacquinod S, Rivas S, Marco Y, Deslandes L. Autoacetylation of the Ralstonia solanacearum effector PopP2 targets a lysine residue essential for RRS1-R-mediated immunity in Arabidopsis. PLoS Pathog 2010; 6(11): e1001202.

48. Cesari S, Bernoux M, Moncuquet P, Kroj T, Dodds PN. A novel conserved mechanism for plant NLR protein pairs: the "integrated decoy" hypothesis. Frontiers in plant science 2014; 5: 606.

49. $\mathrm{Hu}$ J, Barlet X, Deslandes L, Hirsch J, Feng DX, Somssich I, Marco Y. Transcriptional responses of Arabidopsis thaliana during wilt disease caused by the soil-borne phytopathogenic bacterium, Ralstonia solanacearum. PLoS One 2008; 3(7): e2589.

50. Ishihara T, Mitsuhara I, Takahashi H, Nakaho K. Transcriptome analysis of quantitative resistance-specific response upon Ralstonia solanacearum infection in tomato. PLoS One 2012; 7(10): e46763.

51. McAvoy T, Freeman J, Rideout S, Olson S, Paret P. Evaluation of Grafting Using Hybrid Rootstocks for Managment of Bacterial Wilt in Field Tomato Production. HortScience 2012; 47(5): 621-625.

52. Rivard CL, O'Connell S, Peet MM, Welker RM, Louws FJ. Grafting Tomato to Manage Bacterial Wilt Caused by Ralstonia solanacearum in the Southeastern United States. Plant Disease 2012; 96(7): 973-978. 
53. Grimault V, Gelie B, Lemattre M, Prior P, Schmit J. Comparative Histology of Resistant and Susceptible Tomato Cultivars Infected by Pseudomonas-Solanacearum.

Physiological and Molecular Plant Pathology 1994; 44(2): 105-123.

54. Grimault V, Prior P. Bacterial Wilt Resistance in Tomato Associated with Tolerance of Vascular Tissues to Pseudomonas-Solanacearum. Plant Pathology 1993; 42(4): 589-594.

55. Nakaho K, Inoue H, Takayama T, Miyagawa H. Distribution and multiplication of Ralstonia solanacearum in tomato plants iwth resistance derived from different origins. Journal of General Plant Pathology 2004; 70(2): 115-119.

56. Turner M, Jauneau A, Genin S, Tavella MJ, Vailleau F, Gentzbittel L, Jardinaud MF. Dissection of bacterial Wilt on Medicago truncatula revealed two type III secretion system effectors acting on root infection process and disease development. Plant Physiol 2009; 150(4): 1713-1722.

57. Digonnet C, Martinez Y, Denance N, Chasseray M, Dabos P, Ranocha P, Marco Y, Jauneau A, Goffner D. Deciphering the route of Ralstonia solanacearum colonization in Arabidopsis thaliana roots during a compatible interaction: focus at the plant cell wall. Planta 2012; 236(5): 1419-1431.

58. Yuliar, Nion YA, Toyota K. Recent trends in control methods for bacterial wilt diseases caused by Ralstonia solanacearum. Microbes and environments / JSME 2015; 30(1): 111.

59. Kurabachew H, Wydra K. Characterization of plant growth promoting rhizobacteria and their potential as bioprotectant against tomato bacterial wilt caused by Ralstonia solanacearum. Biological Control 2013; (67): 75-83.

60. Huang J, Wei Z, Tan S, Mei X, Yin S, Shen Q, Xu Y. The rhizosphere soil of diseased tomato plants as a source for novel microorganisms to control bacterial wilt. Applied Soil Ecology 2013; (72): 79-84.

61. Hyakumachi M, Nishimura M, Arakawa T, Asano S, Yoshida S, Tsushima S, Takahashi H. Bacillus thuringiensis supresses bacterial wilt disease caused by Ralstonia solanacearum with systemic induction of defense-related gene expression in tomato. . Microbes and environments / JSME 2013; (28: 128-134).

62. Takahashi H, Nakaho K, Ishihara T, Ando S, Wada T, Kanayama Y, Asano S, Yoshida S, Tsushima S, Hyakumachi M. Transcriptional profile of tomato roots exhibiting Bacillus thuringiensis-induced resistance to Ralstonia solanacearum. Plant cell reports 2014; 33(1): 99-110.

63. Pieterse CM, Zamioudis C, Berendsen RL, Weller DM, Van Wees SC, Bakker PA. Induced systemic resistance by beneficial microbes. Annu Rev Phytopathol 2014; 52: 347-375. 
64. Hase S, Shimizu A, Nakaho K, Takenaka S, Takahashi H. Induction of transient ethylene and reduction in severity of tomato bacterial wilt by Pythium oligandrum. Plant Pathology 2006; 55(4): 537-543.

65. Zhu HH, Yao Q. Localized and systemic increase of phenols in tomato root induced by Glomus versiformae inhibits Ralstonia solanacearum. Journal of Phytopathology 2004; (152): 537-542.

66. Tahat MM, Siiam K, Othman R. The potential of endomycorrhizal fungi in controllng tomato bacterial wilt Ralsotnia solanacearum under glasshouse coditions. . African Journal of Biotechnology 2012; (11): 13085-13094.

67. Nerome M, Toyota K, Islam TM, Nishimima T, Matsuoka T, Sato K, Yamaguchi Y. Suppression of bacterial wilt of tomato by incorporation of municipal biowaste charcoal into soil. Soil Microorganisms 2005; 59(1): 9 -14.

68. Liu L, Sun C, Liu S, Chai R, Huang W, Liu X, Tang C, Zhang Y. Bioorganic fertilizer enhances soil suppressive capacity against bacterial wilt of tomato. PLoS One 2015; 10(4): e0121304.

69. Kiirika LM, Stahl F, Wydra K. Phenotypic and molecular characterization of resistance induction by single and combined application of chitosan and silicon in tomato against Ralstonia solanacearum. Physiological and Molecular Plant Pathology 2013; (81): 1 12.

70. Ghareeb H, Bozso Z, Ott PG, Repenning C, Stahl F, Wydra K. Transcriptome of siliconinduced resistance against Ralstonia solanacearum in the silicon non-accumulator tomato implicates priming effect. Physiological and Molecular Plant Pathology 2011; (75): 8389.

71. Kang Y, Saile E, Schell MA, Denny TP. Quantitative immunofluorescence of regulated eps gene expression in single cells of Ralstonia solanacearum. Applied and environmental microbiology 1999; 65(6): 2356-2362.

72. Dalsing BL, Allen C. Nitrate assimilation contributes to Ralstonia solanacearum root attachment, stem colonization, and virulence. J Bacteriol 2014; 196(5): 949-960.

73. Schell MA, Roberts DP, Denny TP. Analysis of the Pseudomonas solanacearum polygalacturonase encoded by pglA and its involvement in phytopathogenicity. $J$ Bacteriol 1988; 170(10): 4501-4508.

74. Tans-Kersten J, Guan Y, Allen C. Ralstonia solanacearum pectin methylesterase is required for growth on methylated pectin but not for bacterial wilt virulence. Applied and environmental microbiology 1998; 64(12): 4918-4923. 
75. Gonzalez ET, Allen C. Characterization of a Ralstonia solanacearum operon required for polygalacturonate degradation and uptake of galacturonic acid. Mol Plant Microbe Interact 2003; 16(6): 536-544.

76. Kang Y, Huang J, Mao G, He L, Schell MA. Dramatically reduced virulence of mutants of Pseudomonas solanacearum defective in export of extracellular proteins across the outer membrane. Mol Plant Microbe Interact 1994; (7): 370-377.

77. Tans-Kersten J, Huang H, Allen C. Ralstonia solanacearum needs motility for invasive virulence on tomato. J Bacteriol 2001; 183(12): 3597-3605.

78. Liu H, Kang Y, Genin S, Schell MA, Denny TP. Twitching motility of Ralstonia solanacearum requires a type IV pilus system. Microbiology 2001; 147(Pt 12): 32153229.

79. Jacobs JM, Milling A, Mitra RM, Hogan CS, Ailloud F, Prior P, Allen C. Ralstonia solanacearum requires PopS, an ancient AvrE-family effector, for virulence and To overcome salicylic acid-mediated defenses during tomato pathogenesis. MBio 2013; 4(6): e00875-00813.

80. Dalsing BL, Truchon AN, Gonzalez-Orta ET, Milling AS, Allen C. Ralstonia solanacearum uses inorganic nitrogen metabolism for virulence, ATP production, and detoxification in the oxygen-limited host xylem environment. MBio 2015; 6(2): e02471.

81. Marenda M, Brito B, Callard D, Genin S, Barberis P, Boucher C, Arlat M. PrhA controls a novel regulatory pathway required for the specific induction of Ralstonia solanacearum hrp genes in the presence of plant cells. Molecular microbiology 1998; 27(2): 437-453.

82. Brito B, Marenda M, Barberis P, Boucher C, Genin S. prhJ and hrpG, two new components of the plant signal-dependent regulatory cascade controlled by PrhA in Ralstonia solanacearum. Molecular microbiology 1999; 31(1): 237-251.

83. Aldon D, Brito B, Boucher C, Genin S. A bacterial sensor of plant cell contact controls the transcriptional induction of Ralstonia solanacearum pathogenicity genes. The EMBO journal 2000; 19(10): 2304-2314.

84. Brito B, Aldon D, Barberis P, Boucher C, Genin S. A signal transfer system through three compartments transduces the plant cell contact-dependent signal controlling Ralstonia solanacearum hrp genes. Mol Plant Microbe Interact 2002; 15(2): 109-119.

85. Occhialini A, Cunnac S, Reymond N, Genin S, Boucher C. Genome-wide analysis of gene expression in Ralstonia solanacearum reveals that the hrpB gene acts as a regulatory switch controlling multiple virulence pathways. Mol Plant Microbe Interact 2005; 18(9): 938-949. 
86. Monteiro F, Genin S, van Dijk I, Valls M. A luminescent reporter evidences active expression of Ralstonia solanacearum type III secretion system genes throughout plant infection. Microbiology 2012; 158(Pt 8): 2107-2116.

87. Vasse J, Genin S, Frey P, Boucher C, Brito B. The hrpB and hrpG regulatory genes of Ralstonia solanacearum are required for different stages of the tomato root infection process. Mol Plant Microbe Interact 2000; 13(3): 259-267.

88. Remigi P, Anisimova M, Guidot A, Genin S, Peeters N. Functional diversification of the GALA type III effector family contributes to Ralstonia solanacearum adaptation on different plant hosts. New Phytol 2011; 192(4): 976-987.

89. Racape J, Belbahri L, Engelhardt S, Lacombe B, Lee J, Lochman J, Marais A, Nicole M, Nurnberger T, Parlange F, Puverel S, Keller H. Ca2+-dependent lipid binding and membrane integration of PopA, a harpin-like elicitor of the hypersensitive response in tobacco. Molecular microbiology 2005; 58(5): 1406-1420.

90. Carney BF, Denny TP. A cloned avirulence gene from Pseudomonas solanacearum determines incompatibility on Nicotiana tabacum at the host species level. $J$ Bacteriol 1990; 172(9): 4836-4843.

91. Robertson AE, Wechter WP, Denny TP, Fortnum BA, Kluepfel DA. Relationship between avirulence gene (avrA) diversity in Ralstonia solanacearum and bacterial wilt incidence. Mol Plant Microbe Interact 2004; 17(12): 1376-1384.

92. Macho AP, Guidot A, Barberis P, Beuzon CR, Genin S. A competitive index assay identifies several Ralstonia solanacearum type III effector mutant strains with reduced fitness in host plants. Mol Plant Microbe Interact 2010; 23(9): 1197-1205.

93. de Lange O, Schreiber T, Schandry N, Radeck J, Braun KH, Koszinowski J, Heuer H, Strauss A, Lahaye T. Breaking the DNA-binding code of Ralstonia solanacearum TAL effectors provides new possibilities to generate plant resistance genes against bacterial wilt disease. New Phytol 2013; 199(3): 773-786.

94. Li L, Atef A, Piatek A, Ali Z, Piatek M, Aouida M, Sharakuu A, Mahjoub A, Wang G, Khan S, Fedoroff NV, Zhu JK, Mahfouz MM. Characterization and DNA-binding specificities of Ralstonia TAL-like effectors. Molecular plant 2013; 6(4): 1318-1330.

95. Sole M, Popa C, Mith O, Sohn KH, Jones JD, Deslandes L, Valls M. The awr gene family encodes a novel class of Ralstonia solanacearum type III effectors displaying virulence and avirulence activities. Mol Plant Microbe Interact 2012; 25(7): 941-953.

96. Chen L, Shirota M, Zhang Y, Kiba A, Hikichi Y, Ohnishi K. Involvement of HLK effectors in Ralstonia solancearum disease development in tomato. J Gen Plant Pathol 2014; 80: 79-84. 
97. Angot A, Peeters N, Lechner E, Vailleau F, Baud C, Gentzbittel L, Sartorel E, Genschik $\mathrm{P}$, Boucher $\mathrm{C}$, Genin S. Ralstonia solanacearum requires F-box-like domain-containing type III effectors to promote disease on several host plants. Proc Natl Acad Sci U S A 2006; 103(39): 14620-14625. 